\title{
Value Co-Creation and Satisfaction in B2B Context: A Triadic Study in the Furniture Industry
}

\author{
Vicente Sales-Vivó $^{1}\left(\mathbb{D}\right.$, Irene Gil-Saura ${ }^{2} \mathbb{D}$ and Martina G. Gallarza ${ }^{2, *(\mathbb{D})}$ \\ 1 Business Analysis and Strategy Section, AIDIMME Technology Institute, 38, 46980 Valencia, Spain; \\ vsales@aidimme.es \\ 2 Marketing Department, University of Valencia, 13, 46010 Valencia, Spain; irene.gil@uv.es \\ * Correspondence: martina.gallarza@uv.es
}

check for

updates

Citation: Sales-Vivó, V.; Gil-Saura, I.; Gallarza, M.G. Value Co-Creation and Satisfaction in B2B Context: A Triadic Study in the Furniture Industry. Sustainability 2021, 13, 152. https:// doi.org/10.3390/su13010152

Received: 10 November 2020 Accepted: 18 December 2020 Published: 25 December 2020

Publisher's Note: MDPI stays neutral with regard to jurisdictional clai$\mathrm{ms}$ in published maps and institutional affiliations.

Copyright: (C) 2020 by the authors. Licensee MDPI, Basel, Switzerland. This article is an open access article distributed under the terms and conditions of the Creative Commons Attribution (CC BY) license (https:// creativecommons.org/licenses/by/ $4.0 /)$.

\begin{abstract}
Research on Value co-Creation $(\mathrm{VcC})$ has been more extensive in B2C (business-to-consumer) than in B2B (business-to-business) and mainly for service contexts, under dyadic approaches (supplier-client). Moreover, research has paid little attention to the impacts of $\mathrm{VCC}$ on Satisfaction in its duality: Social and Economic Satisfaction. As a novelty, this study examines VcC in B2B industrial relationships in the triad of supplier-manufacturer-client. A model proposes $\mathrm{VcC}$ as an antecedent of manufacturer's Economic Satisfaction, with the mediating role of Social Satisfaction. The model is empirically contrasted for a sample of 77 firms from an industrial panel—the Spanish Furniture Market Observatory. The triadic approach is depicted with bi-directional relationships of the manufacturer with its main supplier and main client). Results evidence that VcC and Economic Satisfaction are greater in the manufacturer-main client relationship. Moreover, the manufacturer's Satisfaction relies on its social dimension, which has a key role to produce Economic Satisfaction. Results also show asymmetry in the supply chain, different from those with the main supplier. Implications for managers invite to achieve a long-term $\mathrm{VcC}$ chain with all business partners, the focus being on manufacturer's social dimension, so the triad supplier-manufacturer-client could be better aligned.
\end{abstract}

Keywords: value co-creation; social satisfaction; economic satisfaction; B2B, supply chain

\section{Introduction}

Value co-Creation $(\mathrm{VcC})$ is currently a major line of research in the marketing literature. The practices of $\mathrm{VcC}$ in $\mathrm{B} 2 \mathrm{~B}$ (business-to-business) relationships, whether industrial or between service companies, are of growing strategic interest for the development of competitive advantages. As widely acknowledged, $\mathrm{VcC}$ has a leading role in the Service-Dominant Logic (SDL) approach [1]. In the SDL mindset, B2B relationships are understood under a new perspective, wherein a service is considered the core of all exchanges. Under this paradigm, value derives from a co-creation between actors in the application of resources in the business relationship [1]. Under the SDL lens, numerous studies have identified strategic business priorities related to the $\mathrm{VcC}$, especially in recent years [2]. Among these priorities, what clearly stands out is the need to develop complex and dynamic co-creation networks through service ecosystems with clients and partners [3,4]. A new priority arises: the creation of Product/Service Systems, in an interaction between tangible and intangible elements in the company, known as "servitization" [5,6], all in a competitive context of globalization and digitalization. In this sense, addressing $\mathrm{VcC}$, both scholarly and managerially, can contribute to more holistic ecosystems in companies and corporations $[7,8]$.

However, although the $\mathrm{VcC}$ is mainstream within the framework of SDL and it has been the subject of numerous calls for research in recent years (e.g. [2,9,10]), its empirical analysis is difficult and controversial [11,12]. As a result, most research on $\mathrm{VcC}$ has focused on business-to-consumer (B2C) relations, while less progress has been made in the area of business-to-business (B2B) relations. Indeed, our review of previous studies coincides 
with that of others $[3,13,14]$ in showing that the B2B field has mainly developed in the context of services (tourism, ICT, health, financial services, etc.), while the industrial manufacturing context has received less attention. More specifically, the study on how VcC varies according to the company's role in the supply chain is limited, either through the dyad approach or the triad approach. The dyad approach deals with the unidirectional relationships of an agent with others, either upwards (from the client to the supplier) or downwards (from the supplier to the client). Otherwise, the triad approach studies the former and the latter relationships $[15,16]$. In this sense, from a triadic approach, studying $\mathrm{VcC}$ interactions between firms in a supply chain (i.e. B2B relationships) should add to the long-term development of companies' ecosystems. Indeed, at an uppermost macro-level, it is clearly acknowledged how socio-economic aspects of human interactions are relevant for sustainable development progress [7]. However, at a micro-level, especially when considering B2B approaches, these socio-economic aspects are less researched.

In sum, several reasons exist for focusing on the impacts of $\mathrm{VcC}$ on $\mathrm{B} 2 \mathrm{~B}$ relationships: (1) there is a need for expanding the B2C findings into the B2B context, specifically in order to complete a holistic view of co-creation from end-users back through the whole supply chain; (2) theory on Satisfaction dimensions needs to be contrasted in different business settings; (3) theoretical models need more clarification on the role of $\mathrm{VcC}$ regarding relational and result variables.

Accordingly, this paper aims to study the concept of $\mathrm{VcC}_{\mathrm{C}}$ and its effect on Satisfaction in the industrial B2B relationship. We focus on industrial manufacturers with a proposed model of mediation of Social Satisfaction in the VcC-Economic Satisfaction chain. The model is empirically contrasted for a sample of 77 firms from an industrial panel-the Spanish Furniture Market Observatory. A triadic approach is adopted with bi-directional relationships of the manufacturer with its main supplier and main client, in order to establish differences along the supply chain.

By using this approach, we wish to enhance knowledge on several aspects scarcely developed in the literature. Firstly, the work considers the manufacturer's VcC in the double direction supplier-manufacturer and manufacturer-client, introducing a novel triad approach. This approach helps to understand the critical role of the industrial manufacturer as an intermediary along the supply chain [16]. In this way, the work enhances the understanding of how the perception of the industrial manufacturer differs according to its role in the supply chain towards the supplier or the main client. Secondly, our study adopts and enriches the research stream that addresses differences in the not-always-clear link between Economic Satisfaction and Social Satisfaction in the industrial B2B relationship [17-19]. In this sense, the study contributes to explain the effect that Social Satisfaction has on Economic Satisfaction. Finally, the study expands the existing knowledge on Satisfaction in $\mathrm{B} 2 \mathrm{~B}$ relations by relating it to $\mathrm{VcC}$, as a contemporary concept on which contributions are lacking regarding its influence on outcome variables such as business Satisfaction.

The paper is organized as follows: after an initial literature review that leads to research questions and model hypotheses, the empirical study conducted with a sample of 77 manufacturing firms is explained. Therefore, results are depicted so key findings, implications, and research limitations are discussed in the final section.

\section{Literature Review and Theoretical Framework}

\subsection{Value Co-Creation in the Industrial B2B Context}

$\mathrm{VcC}$ in $\mathrm{B} 2 \mathrm{~B}$ environments is a concept derived from consumer behavior and strategic marketing literature, resulting in abundant research on perceived value in B2C contexts [20-22], in its measurement and modeling. Value is usually considered as a mediating variable in means-end models between antecedent variables (price and quality, mainly) and consequent variables or results (loyalty and behavioral intentions, mainly). At the same time, the literature on strategic marketing adds basic variables such as trust and commitment in addition to Satisfaction, to understand B2B relationships in industrial contexts. 
Conceptually, there is no agreed definition of $\mathrm{VcC}$. Different research streams introduce co-creation as a consumer involvement matter, a service issue, or an innovation process, which broadens the role of interactions and stakeholders under different but related activities (e.g. co-production and prosumption) $[2,9,10]$. However, both in the consumer literature and in the strategic marketing literature, there is unanimity on the customer centrality in creating value. In both traditions, value is phenomenological, cocreated, and multidimensional $[23,24]$, which implies that value does not reside in the products or services offered, but in the experience itself.

Other authors point out the dynamic nature of $\mathrm{VcC}$, underlining the existence of stages, processes, and episodes throughout the business relationship [10]. The dynamic nature of value is also reflected in the interest aroused by the interactions of the concept with the capabilities and resources of the company [4].

Another prominent aspect in the literature on $\mathrm{VcC}$ in the context of SDL is its collaborative, interactive, and reciprocal characteristics, clearly synergistic in nature [14]. VcC implies collaboration with a network or ecosystem of agents in the company's environment, both suppliers and customers where the end customer occupies a central axis [3,24].

More specifically, when it comes to $\mathrm{VcC}$ in the $\mathrm{B} 2 \mathrm{~B}$ relationship, there is a wide variety of approaches to the concept. In light of the review carried out, there is consensus in considering information exchanges and collaboration as essential $\mathrm{VcC}$ practices between companies. Kohtamäki and Partanen [15], for example, employ a relational learning scale in regard to the transmission of information between the manufacturer and the customer in the context of knowledge-intensive industrial services. On the other hand, a collaboration between B2B agents is often reflected in the existence of common planning practices, joint problem solving, and flexibility in unforeseen situations or situations that require adaptation [25]. Other authors have approached the question by studying the level of business readiness for the strategic $\mathrm{VcC}$, as is the case of the DART scale proposed by Albinsson et al. [26], which measures dimensions of co-Creation such as dialogue, access, risk assessment, and transparency between partners. Furthermore, in their study, these authors incorporate shared responsibility between partners as a variable in their model, in contrast with other authors including it as an attribute of $\mathrm{VcC}$ (for example, in Claro and Claro [25]).

By way of synthesis of this review, Table 1 summarises the most recent approaches adopted in the $\mathrm{VcC}$ literature.

Table 1. Recent perspectives on Value co-Creation $(\mathrm{VcC})$ research in business-to-business (B2B) contexts.

\begin{tabular}{|c|c|c|}
\hline Approach & Authors & Refs \\
\hline \multirow{2}{*}{ Customer centrality } & Kohtamäki and Rajala (2016) & [3] \\
\hline & Vargo et al. (2017) & [24] \\
\hline \multirow{4}{*}{ Synergic construct } & Nätti et al. (2014) & [16] \\
\hline & Zhang et al. (2015) & [14] \\
\hline & Kohtamäki and Rajala (2016) & [3] \\
\hline & Vargo et al. (2017) & {$[24]$} \\
\hline Dynamic nature & Ranjan and Read (2016) & [10] \\
\hline \multirow{2}{*}{ Dimensionality } & Kohtamäki and Partanen (2016) & [15] \\
\hline & Albinsson et al. (2016) & [26] \\
\hline \multirow{3}{*}{$\begin{array}{l}\text { Interaction with operant resources and } \\
\text { firm's capabilities }\end{array}$} & Zhang et al. (2015) & [14] \\
\hline & Hamidi and Gharneh (2017) & [27] \\
\hline & Hsu (2016) & [28] \\
\hline \multirow{6}{*}{ As relational variable } & Franklin and Marshall (2019) & [29] \\
\hline & Woratschek et al. (2019) & [30] \\
\hline & Merz et al. (2018) & [31] \\
\hline & Berenguer-Contrí et al. (2018) & [32] \\
\hline & Thiruvattal (2017) & [33] \\
\hline & Cossío-Silva et al. (2016) & [34] \\
\hline
\end{tabular}




\subsection{Satisfaction in the Industrial B2B Relationship}

Satisfaction with a B2B relationship is understood as "an affective state resulting from the appraisal of different aspects of the relationship" [35] (p. 63). Satisfaction is a global evaluation and an indicator of the effectiveness of the relationship between partners, as well as a predictor of continuity $[19,36]$.

To provide long-term relationships in the supply chain, Satisfaction should be presented in two ways: Economic, on the one hand, and Social or non-Economic, on the other [37]. Economic Satisfaction is the positive evaluation that a company makes of the economic results or benefits obtained due to their relationship with another company (volume of purchases, margins, discounts, etc.). Social Satisfaction is defined as the gratifying evaluation that the company makes of interactions with the other party and focuses on the psychosocial aspects of the relationship (ease of doing business, communication, shared values, etc.). Geyskens and Steenkamp [37] conceptually differentiate between both components of Satisfaction in B2B relationships, since each dimension arises from different practices and presents different implications for the relationship.

Satisfaction is usually presented as a consequence of the business relationship. However, this causality is not always clear, and it has been also considered as part of the relationship quality construct alongside other variables such as trust $[18,19,38]$. Similarly, the direction of the chain of effects between the two types of Satisfaction is not always obvious. In general, Ha et al. [18] show the importance of Social Satisfaction in the B2B relationship over time, in comparison with Economic Satisfaction and its position between perceived value and trust. In the industrial B2B context, Ferro et al. [17] study the causal relationships between Economic Satisfaction and Non-Economic Satisfaction, although they do not obtain evidence of the direction of the effect of one on the other. As a summary, Table 2 describes the main bibliographic references on B2B relations supporting this study.

Table 2. Main references of the literature review in B2B contexts.

\begin{tabular}{|c|c|c|c|}
\hline Year & Journal & Authors & Refs \\
\hline 2000 & Journal of Retailing & Geyskens and Steenkamp (2000) & [37] \\
\hline 2006 & Industrial Marketing Management & Rodríguez del Bosque et al. (2006) & [19] \\
\hline \multirow{2}{*}{2010} & Industrial Marketing Management & Claro and Claro (2010) & [25] \\
\hline & Journal of Business Research & Svensson et al. (2010) & [38] \\
\hline 2012 & Industrial Marketing Management & O'Cass and Ngo (2012) & [4] \\
\hline 2014 & Industrial Marketing Management & Nätti et al. (2014) & [16] \\
\hline \multirow{4}{*}{2016} & European Journal of Marketing & Ha et al. (2016) & {$[18]$} \\
\hline & Industrial Marketing Management & Kohtamäki and Rajala (2016) & [3] \\
\hline & Journal of Business \& Industrial Marketing & Ferro et al. (2016) & {$[17]$} \\
\hline & Journal of Business Research & $\begin{array}{l}\text { Kohtamäki and Partanen (2016) } \\
\text { Cossío-Silva et al. (2016) }\end{array}$ & $\begin{array}{l}{[15]} \\
{[34]}\end{array}$ \\
\hline 2017 & Journal of Global Operations and Strategic Sourcing & Thiruvattal, E. (2017) & {$[33]$} \\
\hline \multirow{2}{*}{2018} & Journal of Business Research & Merz et al. (2018) & [31] \\
\hline & Management Decision & Ruiz-Martinez et al. (2018) & {$[39]$} \\
\hline \multirow{2}{*}{2019} & Industrial Marketing Management & Franklin and Marshall (2019) & [29] \\
\hline & The Service Industries Journal & Woratschek et al. (2019) & {$[30]$} \\
\hline 2020 & Journal of Service Research & Bond et al. (2020) & {$[40]$} \\
\hline
\end{tabular}




\subsection{Research Questions, Hypotheses, and Model of Mediation Between VcC and Satisfaction}

For the methodological design, we look to previous studies that have explored the dyad or triad approach in the study of $\mathrm{VcC}$ in the industrial B2B relationship (e.g. $[15,16])$. We also review other works on Satisfaction in the B2B relationship, establishing the difference between Economic Satisfaction and Social Satisfaction [17-19]. Integrating these previous contributions, we first propose the existence of differences in the assessment that the manufacturer makes of $\mathrm{VcC}$ and the Social and Economic Satisfaction between its main supplier and its main customer. To do this, the following research questions are raised:

Q1. Is VcC in the manufacturer's relationship with its main supplier different than with its main customer?

Q2. Is Social Satisfaction in the manufacturer's relationship with its main supplier different than with its main customer?

Q3. Is Economic Satisfaction in the manufacturer's relationship with its main supplier different than with its main customer?

Second, there is an important line of research that proposes causal models where $\mathrm{VcC}$ is presented under different roles in its relationship with other concepts. Some authors relate $\mathrm{VcC}$ with the company's operating resources and results (e.g. Hamidi and Gharneh [27]). Zhang et al. [14] add the innovation capability, the marketing and networking capabilities of the company to model the relationship between these capabilities and the $\mathrm{VcC}$ and, as variables resulting from their model, the brand capital, and the customer value. O'Cass and Ngo [4] show the relationship between $\mathrm{VcC}$ and market orientation, product innovation capability, and marketing capabilities with all results (business performance value and relational value) validated through control variables (company size and type of market). Ngo and $\mathrm{O}^{\prime}$ Cass [41] study the importance of operating resources (production, innovation, and marketing capability) on $\mathrm{VcC}$, understood as a dimension of the company's value proposition. Hsu [28], on the other hand, models the VcC strategy with the marketing, the innovation and the design strategies, and the new product development as a result variable in its model.

Along these lines, the theory presents numerous models where $\mathrm{VcC}$ interacts with other B2B relational variables such as trust or commitment between partners. These variables have been considered precursors of customer value or of the business relationship [32], but causality is not always evident. In fact, the literature presents examples where $\mathrm{VcC}$ plays different roles in the B2B relationship. For example, as an antecedent (e.g. Cossío-Silva et al. [34], Franklin and Marshall [29], Thiruvattal [33]) or as a consequence (e.g. Merz et al. [31], O'Cass and Ngo [4]). Although scarce, in the B2B field, VcC can act as an antecedent for other relational variables, such as customer satisfaction and loyalty [30]. Last, there are also mediating variables such as superior service solutions or collaboration in the supply chain [33].

Based on these previous works, to explore the aforementioned questions, we propose a regression model with mediation, applied to the relationship between the manufacturer and its supplier or its main customer, where the effect of $\mathrm{VcC}$ on Economic Satisfaction is mediated by Social Satisfaction. Figure 1 shows the proposed model, with the corresponding hypotheses, raised for both directions of the triad (A and B).

H1. The manufacturer's VcC has a direct and positive effect on Social Satisfaction, in the relationship with its main supplier (H1A) and/or with its main customer (H1B).

H2. The manufacturer's VcC has a positive effect on Economic Satisfaction, in the relationship with its main supplier (H2A) and/or with its main customer (H2B).

H3. The Social Satisfaction of the manufacturer acts as a mediator of the effect of VcC on Economic Satisfaction, in the relationship with its main supplier (H3A) and/or with its main customer (H3B). 


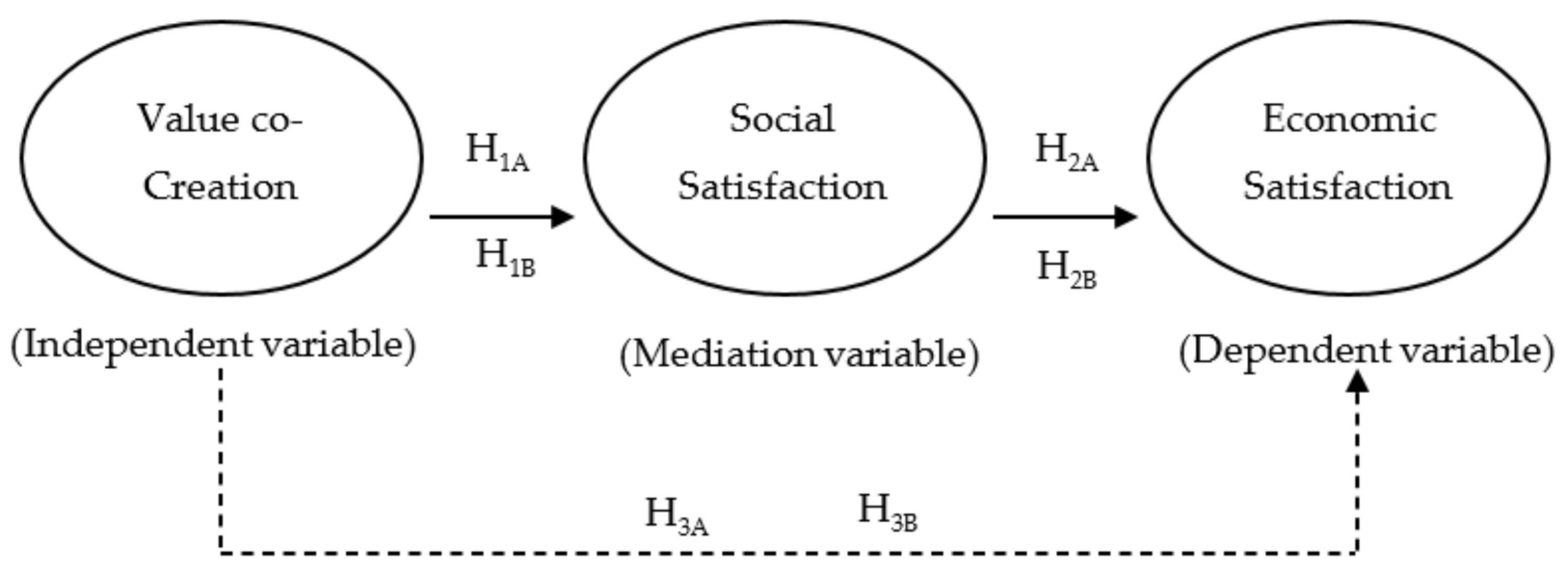

Figure 1. Mediation model of Social Satisfaction between Value Co-Creation and Economic Satisfaction.

\section{Materials and Methods}

\subsection{Data Collection and Sample}

To address the objective of this work, a quantitative investigation has been designed with a structured questionnaire. Senior managers (CEO, marketing or sales directors, etc.) or middle managers (responsible for purchasing, administration, etc.) of manufacturing companies evaluated the $\mathrm{VcC}$ in a double direction following the triad approach: with their main supplier (Sample A) and with their main customer (Sample B), in accordance with the volume of purchases or sales for the reporting company.

The scope of this work is the furniture industry, a sector which lacks of studies in this field [39]. Spain's furniture industry is characterised by the high fragmentation of SME producers (6,962 manufacturing companies turned over 4,608 million Euros in 2019) and the concentration of sales ( $1 \%$ of manufacturers accounted for $42 \%$ of operating income in 2017) [42]. Furniture manufacturers' relationships are developed both with their suppliers of materials (boards, fittings, varnishes, etc.), as well as with shops and retailers (specialised in furniture and non-specialised, such as larger DIY and construction stores, department stores and hypermarkets).

Data was collected on a national level in October 2017, from a sample of panellist companies participating in the Spanish Furniture Market Observatory, led by AIDIMME (Technological Institute). This is an industrial panel that has measured the sector's activity on a quarterly basis since 1998. The Observatory is made up of companies in the supply chain, with the participation of suppliers of materials, furniture manufacturers (contemporary, classic, office, kitchen, and bathroom, etc.) and retailers. For this research, the collaboration of the companies was requested in an ad-hoc specific wave. The initial census was 240 panellist companies, from which 77 valid questionnaires were collected (response rate of $32.1 \%$ ). The manufacturer (a single informant) evaluated, in order to study the triad, $\mathrm{VcC}$ and Satisfaction with its main supplier (sample A) and with its main customer (sample B). Questionnaires were administered by professional pollsters on the phone within an overall month timeframe for responses. Data analysis was performed using the statistical software packages SPSS and SmartPLS [43]. Table 3 summarises the main characteristics of the reporting companies for the study. 
Table 3. Sample firm and respondents' profiles.

\begin{tabular}{lr}
\hline Sample firm profiles & $\%$ \\
\hline Years & \\
$<10$ & 2.7 \\
{$[11,30]$} & 48.0 \\
{$[31,50]$} & 41.3 \\
$>50$ & 8.0 \\
\hline Size & 39.7 \\
Micro (<10 employees) & 48.7 \\
Small (10 to 50 employees) & 10.3 \\
Medium (51 to 250 employees) & 1.3 \\
Large (>250 employees) & 39.4 \\
\hline Annual turnover & 31.0 \\
$<1$ million $€$ & 11.3 \\
1 to 3 million $€$ & 15.5 \\
3 to 6 million $€$ & 2.8 \\
6 to 15 million $€$ & \\
$>15$ million $€$ & 44.7 \\
\hline Respondents Position & 31.6 \\
CEO/General Manager & 23.7 \\
Sales/Marketing Manager & \\
Others (Purchases, Administration ... ) & \\
\hline
\end{tabular}

\subsection{Statistical Power of the Sample}

Before examining the existence of significant differences in the responses of the samples, we performed a power test to confirm the suitability of the samples [44]. The test power has been estimated with the $G^{*}$ Power software application version 3.1.9.2. The two data samples $A$ and $B$ have a power of $(1-\beta)=0.86(86 \%)$, for $n=77$. In both cases, an $\alpha=0.05$ and a strong effect size (0.3) were applied to check the test power. The result of this test confirms that the two samples exceed $80 \%$ of the statistical power required in social sciences, according to the literature [45].

\subsection{Measurement Development}

To measure the $\mathrm{VcC}$ construct, we chose the approach of collaboration between companies adopting Claro and Claro [25]'s scale, from their research on collaboration in the supplier-customer relationship and information on distribution channels. The measurement scale reflects this collaborative framework, where solutions are sought constructively by both parties in the B2B relationship, rather than in a coercive or dominant way by one part. The scale is made up of six indicators, which respond to the main aspects of collaboration between companies, namely: new product development, long-term planning, problem-solving, shared responsibility, flexibility, and response to unexpected situations. These indicators are reflected in the measurement scale, which has been treated in a unidimensional way.

On the one hand, for the Economic and Social Satisfaction variables, we adapted scales proposed by Chung et al. [46], with three indicators each, using seven-point Likert scales. Indicators for Economic Satisfaction reflect the improvement in the market position, sales, and effectiveness achieved due to the relationship with the business partner. On the other hand, indicators for Social Satisfaction reflect mutual respect, the overall working relationship, and willingness to choose the same business partner again.

\section{Results}

\subsection{Principal Components Analyses for VcC and Satisfaction}

Before examining the significant differences in the responses of the two samples (A and B), we carried out an Exploratory Factor Analysis to find out the dimensionality 
of the variables $\mathrm{VcC}$ and Satisfaction in a dual Social and Economic approach. Through a Principal Component Analysis (PCA) we verify that $\mathrm{VcC}$ is presented in a unidimensional way and explains $54.28 \%$ of the total variance in the case of sample A (relationship between the manufacturer and the main supplier), and $62.53 \%$ in sample B (relationship between the manufacturer and the main customer). As it is a unidimensional variable, the rotation of the factors has not been necessary.

In the same way, we carried out the Exploratory Factor Analysis on Social Satisfaction and verified that its only dimension explains $72.47 \%$ of the total variance in sample A and $80.44 \%$ in sample B. Economic Satisfaction, also unidimensional, explains $74.46 \%$ of the total variance in sample A and $71.00 \%$ in sample B.

\subsection{Reliability and Validity of the Measurement Scales}

Next, we present the corresponding reliability and validity contrasts of the measurement scales for the variables VcC, Social Satisfaction, and Economic Satisfaction (cf. Tables 4 and 5). In light of the results, no items were removed from the initial scales.

Table 4. Reliability and convergent validity of Value co-Creation, Social Satisfaction, and Economic Satisfaction unidimensional scales.

\begin{tabular}{ccccccc}
\hline & \multicolumn{2}{c}{ (Sample A) } & \multicolumn{2}{c}{$\begin{array}{c}\text { (Sample B) } \\
\text { Manufacturer and Main Supplier }\end{array}$} & Manufacturer and Main Client \\
\hline $\begin{array}{c}\text { Scales (Number of } \\
\text { Items) }\end{array}$ & $\begin{array}{c}\text { Reliability } \\
\text { (Cronbach's } \boldsymbol{\alpha})\end{array}$ & $\begin{array}{c}\text { Composite } \\
\text { Reliability }\end{array}$ & $\begin{array}{c}\text { Average } \\
\text { Variance } \\
\text { Extracted }\end{array}$ & $\begin{array}{c}\text { Reliability } \\
\text { (Cronbach's } \boldsymbol{\alpha} \text { ) }\end{array}$ & $\begin{array}{c}\text { Composite } \\
\text { Reliability }\end{array}$ & $\begin{array}{c}\text { Average } \\
\text { Variance } \\
\text { Extracted }\end{array}$ \\
\hline Value co-Creation (6) & 0.831 & 0.876 & 0.541 & 0.880 & 0.909 & 0.624 \\
\hline Social Satisfaction (3) & 0.808 & 0.887 & 0.724 & 0.878 & 0.925 & 0.804 \\
\hline Economic Satisfaction (3) & 0.827 & 0.895 & 0.741 & 0.795 & 0.879 \\
\hline
\end{tabular}

Table 5. Discriminant validity of Value Co-Creation, Social Satisfaction, and Economic Satisfaction scales.

\begin{tabular}{|c|c|c|c|c|}
\hline & & Value Co-Creation & $\begin{array}{c}\text { Social } \\
\text { Satisfaction }\end{array}$ & $\begin{array}{c}\text { Economic } \\
\text { Satisfaction }\end{array}$ \\
\hline \multirow{3}{*}{$\begin{array}{l}\text { (Sample A) } \\
\text { Manufacturer and main supplier }\end{array}$} & Value co-Creation & 0.736 & 0.695 & 0.893 \\
\hline & Social Satisfaction & 0.592 & 0.851 & 0.710 \\
\hline & Economic Satisfaction & 0.744 & 0.603 & 0.861 \\
\hline \multirow{3}{*}{$\begin{array}{l}\text { (Sample B) } \\
\text { Manufacturer and main client }\end{array}$} & Value co-Creation & 0.790 & 0.700 & 0.808 \\
\hline & Social Satisfaction & 0.623 & 0.897 & 0.681 \\
\hline & Economic Satisfaction & 0.684 & 0.578 & 0.842 \\
\hline \multicolumn{5}{|c|}{$\begin{array}{l}\text { Values in the diagonal are AVE squared roots } \\
\text { Under diagonal: factors correlations (Fornell-Larcker criterion) } \\
\text { Over diagonal: HTMT ratio (Heterotrait-Monotrait) }\end{array}$} \\
\hline
\end{tabular}

Reliability makes it possible to know the stability or consistency of the scales used, so the higher the reliability, the lower the variability of the results offered by the measuring instrument. In this study, the three scales used have Cronbach's alpha values close to or greater than 0.8 and indicators of composite reliability greater than 0.9 , which are acceptable for the two study samples.

On the other hand, since the one-dimensionality of the scales used is an indicator of convergent validity, this is further demonstrated, as the mean extracted variance exceeds the minimum value of 0.5 in the scales in both study samples.

The validity tests allow us to verify that the scales accurately measure the concepts of $\mathrm{VcC}$, Social Satisfaction, and Economic Satisfaction, with no overlapping with other con- 
cepts. Content validity, that is, the scale represents the concept it measures, is guaranteed by the theoretical foundation underlying the scales used and its prior validation in the original studies $[25,46]$.

Discriminant validity verifies that the scales do not measure concepts other than those for which they were created. We carry out this verification with two complementary methods: first, the square root of the mean-variance extracted from each variable is higher than its correlation with the other variables in the study (Fornell-Larcker criterion); secondly, the correlations of the items of one variable are higher than the correlations of items measuring other variables, known as the Heterotrait-Monotrait ratio, which must be less than one [47].

Finally, the internal consistency, the factor analysis carried out, and the theoretical foundation of each variable allow us to check the validity of the concept (each scale measures a specific variable). In addition, the revised theory supports the existence of a nomological network between $\mathrm{VcC}$ and Satisfaction in the field of B2B relationships, which in turn confirms the nomological validity of the proposed variables.

\subsection{Mean Comparison of VcC and Satisfaction of the Manufacturer with its Main Supplier and with its Main Customer}

After analyzing the psychometric properties of the scales and rejecting the normality hypothesis, it is considered appropriate to apply the nonparametric Mann-Whitney U test. The rationale for this is to analyze whether or not there are significant differences between $\mathrm{VcC}$ and Satisfaction upwards (with the main supplier) and downwards (with the main customer) in the supply chain.

Through this analysis, we compare the means obtained in the items described in the samples. The purpose of using this technique is to contrast independent samples, where the variable to be compared does not follow a normal distribution. The results derived from the comparison of means of the $\mathrm{VcC}$ variable between the manufacturer's relationship with its main supplier and with its main customer are presented below. Table 6 presents the descriptive statistics and $\mathrm{U}$ Test for $\mathrm{VcC}$ and Economic and Social Satisfaction, comparing samples A and B.

The nonparametric Mann-Whitney $\mathrm{U}$ test indicates that the difference between the The nonparametric Mann-Whitney $U$ test indicates that the difference between the manufacturers' responses in relation to $\mathrm{VcC}$ with their main supplier and with their main customer does not present significant differences in four items $(\mathrm{VcC} 1, \mathrm{VcC} 2, \mathrm{VcC} 3$, and VcC6). However, through the U Test, we can affirm that the responses of the two samples are significantly different in relation to the shared responsibility to achieve the objectives $(\mathrm{VcC} 4)$ and in terms of flexibility in the face of changes in the relationship (VcC5). In both items, the values are higher in sample B, indicating a greater shared responsibility and greater flexibility of the manufacturer with its main customer, compared to that experienced with its main supplier. This allows us to partially answer research question Q1 since samples A and B differ in two of the six $\mathrm{VcC}$ items.

In addition, the $\mathrm{U}$ Test confirms that there are no significant differences in any of the items of the manufacturer's Social Satisfaction with its main supplier and main customer. These results do not allow an affirmative answer to the research question Q2. Regarding Economic Satisfaction, results show the absence of significant differences for items SATE2 and SATE3, but not for SATE1, which reflects a greater relevance in the manufacturer's market position, derived from working with its main client. These results allow us to partially validate the research question Q3. 
Table 6. Descriptive statistics and Mann-Whitney U test of Value co-Creation, Economic Satisfaction, and Social Satisfaction variables.

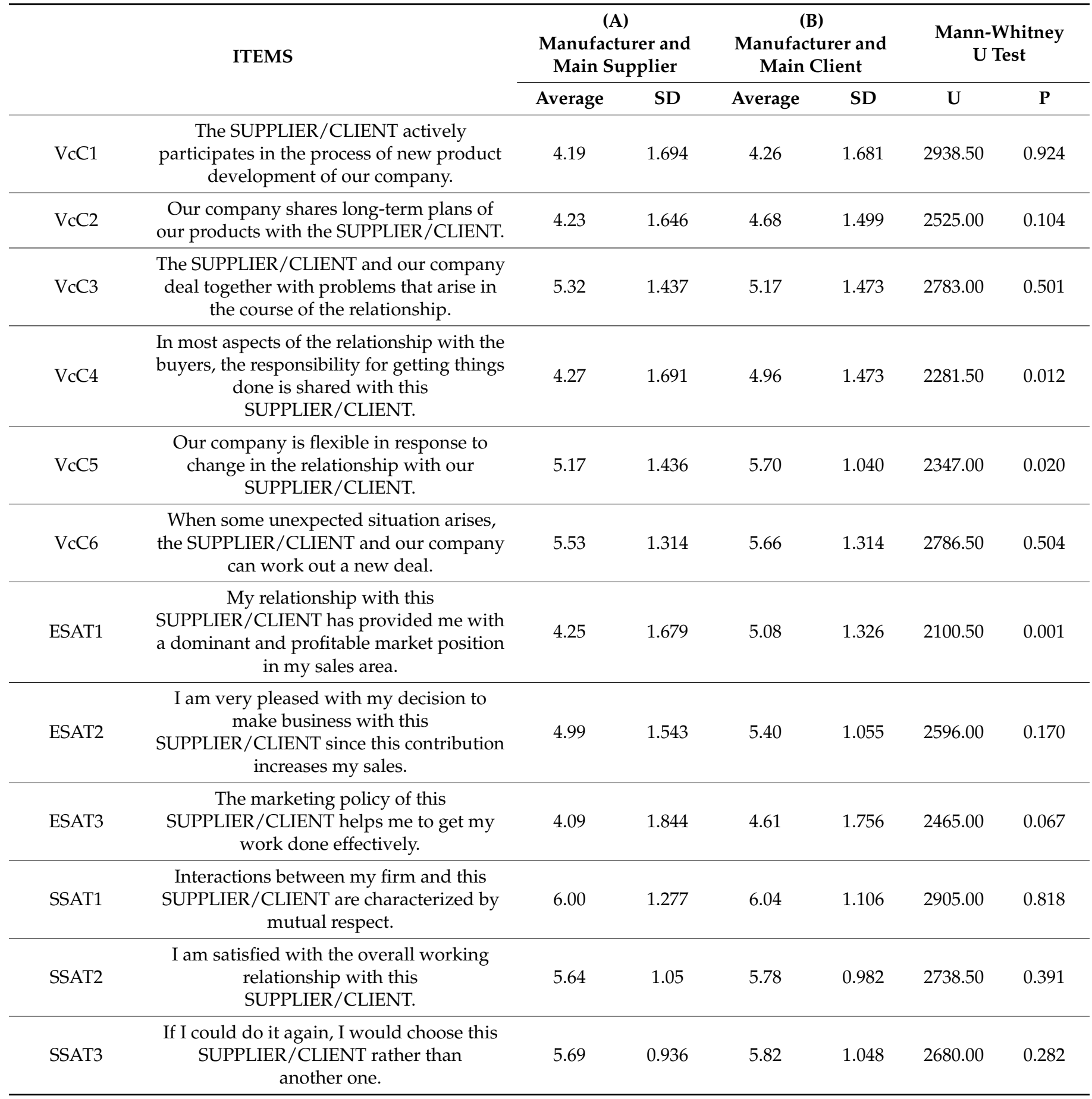

4.4. Regression Model with the Mediation of Social Satisfaction between VcC and Economic Satisfaction

We checked the regression model with mediation through a series of regression equations with the factorial scores of each of the model variables. In this way, we have verified the following necessary conditions to contrast the mediation of one concept between two others, following the four-step analysis method [48-51]: 
(1) Regression equation 1: the first condition is that the independent variable affects the mediator in this first equation. To do this, the influence of $\mathrm{VcC}$ (independent variable of the model) on Social Satisfaction (mediating variable of the model) is analyzed, with $\mathrm{VcC}$ acting as an explanatory variable in this equation and Social Satisfaction as an explained variable.

(2) Regression equation 2: the second condition implies that the independent variable affects the dependent variable in the corresponding equation. To do this, the influence of $\mathrm{VcC}$ (independent variable of the model) on Economic Satisfaction (dependent variable of the model) is analyzed, with $\mathrm{VcC}$ acting as an explanatory variable in this equation and Economic Satisfaction as an explained variable.

(3) Regression equation 3: the mediator must affect the dependent variable in the third regression equation. To do this, the influence of $\mathrm{VcC}$ (independent variable of the model) and Social Satisfaction (mediating variable) on Economic Satisfaction (dependent variable) is analyzed, with $\mathrm{VcC}$ and Social Satisfaction acting as explanatory variables in this equation and Economic Satisfaction as an explained variable.

(4) Condition for the validation of the regression model with mediation: the effect of the independent variable $(\mathrm{VcC})$ on the dependent variable (Economic Satisfaction) must cease to exist in the third equation with respect to the second for the mediation to be perfect or decrease so that the mediation is partial. Therefore, the influence of $\mathrm{VcC}$ on Economic Satisfaction should be lower when it is considered together with Social Satisfaction than when it is analyzed in isolation. If the effect of $\mathrm{VcC}$ on Economic Satisfaction totally disappears in the third equation, then the mediation of Social Satisfaction between both would be perfect.

If all four conditions are met, then we can accept the existence of mediation. For this, we have compared the proposed equations for both samples (cf. Tables 7-9).

Table 7. Regression equation 1 of the regression model with mediation between Value Co-Creation, Social Satisfaction, and Economic Satisfaction.

\begin{tabular}{ccc}
\hline & $\begin{array}{c}\text { (Sample A) } \\
\text { Manufacturer and Main } \\
\text { Supplier }\end{array}$ & $\begin{array}{c}\text { (Sample B) } \\
\text { Manufacturer and Main } \\
\text { Client }\end{array}$ \\
\hline Regression Equation 1: VcC $\rightarrow$ Social Satisfaction \\
\hline Independent & $\begin{array}{c}\text { Dependent } \\
\text { Variable }\end{array}$ & $\begin{array}{c}\text { Variable Dependent } \\
\text { Social Satisfaction }\end{array}$ \\
\hline Value co-Creation & $0.569 * *$ & 0.613 \\
& $(5.998)$ & $(6.714)$ \\
Constant & 0.569 & 0.613 \\
R & $-9.969 \times 10^{-17}$ & $-2.649 \times 10^{-16}$ \\
R2 & $(0.000)$ & $(0.000)$ \\
Adjusted R2 & 0.569 & 0.613 \\
\hline Standard Error of Estimation & 0.324 & 0.375 \\
F Model & 0.315 & 0.367 \\
\hline Durbin-Watson & 0.8275 & 0.7956 \\
\hline ** Significance level at 0.01. & $35.976 * *$ & 45.071 \\
\hline
\end{tabular}


Table 8. Regression equation 2 of the regression model with mediation between Value Co-Creation, Social Satisfaction, and Economic Satisfaction.

\begin{tabular}{ccc}
\hline \multicolumn{2}{c}{ Regression Equation 2: VcC $\rightarrow$ Economic Satisfaction } \\
\hline $\begin{array}{c}\text { Independent } \\
\text { Variable }\end{array}$ & $\begin{array}{c}\text { Dependent } \\
\text { Variable Economic } \\
\text { Satisfaction }\end{array}$ & $\begin{array}{c}\text { Dependent } \\
\text { Variable Economic } \\
\text { Satisfaction }\end{array}$ \\
\hline Value co-Creation & $0.741^{* *}$ & $0.676^{* *}$ \\
& $(9.551)$ & $(7.953)$ \\
Constant & 0.741 & 0.676 \\
R & $-6.269 \times 10^{-17}$ & $-1.534 \times 10^{-16}$ \\
R2 & $(0.000)$ & $(0.000)$ \\
Adjusted R2 & 0.741 & 0.676 \\
Standard error of Estimation & 0.549 & 0.457 \\
\hline F Model & 0.543 & 0.450 \\
\hline Durbin-Watson & 0.6762 & 0.7414 \\
\hline ** Significance level at 0.01. & $91.228^{* *}$ & $63.248^{* *}$ \\
\hline
\end{tabular}

Table 9. Regression equation 3 of the regression model with mediation between Value Co-Creation, Social Satisfaction and Economic Satisfaction.

\begin{tabular}{|c|c|c|}
\hline \multicolumn{3}{|c|}{ Regression Equation 3: VcC and Social Satisfaction $\rightarrow$ Economic Satisfaction } \\
\hline $\begin{array}{l}\text { Independent } \\
\text { Variable }\end{array}$ & $\begin{array}{c}\text { Dependent } \\
\text { Variable Economic } \\
\text { Satisfaction }\end{array}$ & $\begin{array}{c}\text { Dependent } \\
\text { Variable Economic } \\
\text { Satisfaction }\end{array}$ \\
\hline Value co-Creation & $\begin{array}{c}0.602 * * \\
(6.642) \\
0.602\end{array}$ & $\begin{array}{c}0.522 * * \\
(5.007) \\
0.522\end{array}$ \\
\hline Social Satisfaction & $\begin{array}{c}0.243 * * \\
(2.683) \\
0.243\end{array}$ & $\begin{array}{c}0.252 * \\
(2.412) \\
0.252\end{array}$ \\
\hline Constant & $\begin{array}{c}-3.844 \times 10^{-17} \\
(0.000)\end{array}$ & $\begin{array}{c}-8.679 \times 10^{-17} \\
(0.000)\end{array}$ \\
\hline $\mathrm{R}$ & 0.767 & 0.705 \\
\hline $\mathrm{R} 2$ & 0.589 & 0.497 \\
\hline Adjusted R2 & 0.578 & 0.483 \\
\hline Standard Error of Estimation & 0.6498 & 0.7187 \\
\hline F Model & $52.985^{* *}$ & 36.562 \\
\hline Durbin-Watson & 2.331 & 1.971 \\
\hline
\end{tabular}

We observe that $\mathrm{VcC}$ has a positive and direct effect on Social Satisfaction in both samples, which allows us to validate hypotheses H1A and H1B. Similarly, VcC has a positive effect on Economic Satisfaction in the two samples, which allows us to validate hypotheses $\mathrm{H} 2 \mathrm{~A}$ and $\mathrm{H} 2 \mathrm{~B}$.

The VcC coefficient is lower when Social Satisfaction mediates in the regression equation on Economic Satisfaction (third equation) than when $\mathrm{VcC}$ acts in isolation (second equation). The condition is met in both samples: in sample A, the effect of $\mathrm{VcC}$ mediated by Social Satisfaction on Economic Satisfaction is lower $(\mathrm{VcC}$ beta $=0.602)$ than when the effect is direct $(\mathrm{VcC}$ beta $=0.741)$; while in sample B the effect of $\mathrm{VcC}$ mediated by Social Satisfaction is lower $(\mathrm{VcC}$ beta $=0.522)$ than when it is direct on Economic Satisfaction $(\mathrm{VcC}$ 
beta $=0.676$ ). The coefficient of Social Satisfaction is less significant in the third equation for sample B (significant at the 0.05 level) than it is for sample A (significant at the 0.01 level).

In addition, we carried out complementary methods to Baron and Kenny's four-step analysis [48], to establish the significance of the indirect effect of the mediation [50,52]. With this method, if the variance of the predictor variable over the dependent due to the indirect effect exceeds $80 \%$, the mediation is perfect, while it is partial between $20 \%$ and $80 \%$, in both cases significant. Otherwise, the existence of mediation below $20 \%$ cannot be accepted. In our case, we estimate the variance due to mediation with the bootstrap method and calculate the standard errors of the estimates in both samples: results confirm the partial mediation of Social Satisfaction in the case of the relationship between the manufacturer and its main customer (variance due to mediation $=22.3 \%$ ). This implies that just over a fifth of the effect of $\mathrm{VcC}$ on Economic Satisfaction is due to the mediation of Social Satisfaction. On the contrary, the results do not allow confirmation of partial mediation in the case of the relationship between the manufacturer and its main supplier (variance due to mediation $=18.5 \%$ ). These results do not permit validation of hypothesis H3A, but they do validate hypothesis H3B, as shown in Table 10.

Table 10. Significance of the indirect effect of Social Satisfaction's mediation between Value CoCreation and Economic Satisfaction.

\begin{tabular}{ccc}
\hline & $\begin{array}{c}\text { (Sample A) } \\
\text { Manufacturer } \\
\text { and Main Supplier }\end{array}$ & $\begin{array}{c}\text { (Sample B) } \\
\text { Manufacturer } \\
\text { and Main Client }\end{array}$ \\
\hline $\begin{array}{c}\text { Estimation of Mediation } \\
\text { Indirect Effect }\end{array}$ & 0.138408 & 0.153012 \\
\hline Standard Error of Estimation & 0.085859198 & 0.079167904 \\
\hline T Value of Indirect Effect & 1.61203462 & 1.932752939 \\
\hline VAF & $18.5 \%$ & $22.3 \%$ \\
\hline Variance Accounted for) & No significance & Partial \\
\hline
\end{tabular}

In sum, our results throw evidence on the different nature of Social and Economic Satisfaction in B2B industrial relations. Regarding the triad supplier-manufacturer-client, our results show that $\mathrm{VCC}$ and Economic Satisfaction are greater in the manufacturer-main client relationship. Moreover, we have contrasted a model where Social Satisfaction plays a mediating role between $\mathrm{VcC}$ and Economic Satisfaction. A partial mediation in the manufacturer-client relationship has been proven, while mediation is not evidenced in the supplier-manufacturer relation. These findings suggest both theoretical and practical implications that are discussed in the following section.

\section{Discussion and Conclusions}

\subsection{Key Findings}

This work allows advances in $\mathrm{VcC}$ research by studying the effect of $\mathrm{VcC}$ on manufacturer's Social and Economic Satisfaction in B2B relationships throughout the industrial supply chain. We have been able to address results in the industrial context that are less common in the $\mathrm{VcC}$ literature, which has devoted the most attention to the relationship between the company and consumer (B2C) (e.g. $[53,54])$ or, in second place, between companies (B2B) in the scope of services.

Key findings of this work point out $\mathrm{VcC}$ as an antecedent of Economic Satisfaction, with the mediation of Social Satisfaction, in manufacturer-client relationships. These findings reinforce previous theories on the differences between social and economic dimensions of Satisfaction. Our findings also evidence differences in B2B relations between partners in the supplier-manufacturer-client triad along the supply chain. 


\subsection{Theoretical Contribution and Novelty}

The theoretical contribution of the article is the effect of $\mathrm{VcC}$ in the chain formed by Social Satisfaction and Economic Satisfaction. Thus, we incorporate a conceptual difference between the Satisfaction variables as indicated by recent studies in the B2B context [17,18]. It should be noted that, although $\mathrm{VcC}$ has received different conceptual treatments in the academic literature, this work opts to measure the concept through a collaboration-like approach between companies applicable to the industrial supply chain. The results confirm the direction of the effect of Social Satisfaction on Economic Satisfaction and the role of the former as a mediating variable between $\mathrm{VcC}$ and the latter in the relationship between the manufacturer and its main customer. However, this does not occur in the relationship with the main supplier. Nevertheless, the mediation of Social Satisfaction, even when it exists, is partial, so it is to be assumed that additional variables would contribute to a better understanding of the effect of $\mathrm{VcC}$ and Economic Satisfaction in the B2B context in both directions of the supply chain.

In addition, we contribute to the theory with the triad approach used to study how the manufacturer's perception varies according to its role in the supply chain. This is one of the few comparative studies within the industrial triad, where VcC and Satisfaction have been measured in two directions: between the manufacturer and its main supplier (upwards), and between the manufacturer and its main customer (downwards). Moreover, our research adds to general models on sustainable development (e.g. Diesendorf [7]) which consider the need to develop personal and organizational skills and to strengthen the sense of community, which in "the case of a corporation, the 'community' may consist of all employees or even all stakeholders" [7] (p. 10). Our research has evidenced the relevance of social ties in "communities", by studying a triad, and highlighting the importance of adopting a broader picture of the main stakeholders (here, suppliers, manufacturers, and clients) to gain corporate development.

\subsection{Managerial Implications}

These results present implications for business management in the industrial context. By comparing the perceptions of a single informant in upward relationships (with the supplier) and downward relationships (with the customer), a more refined and granular analysis of the industrial chain is allowed. Our results reveal asymmetries in the relationship of the manufacturer with the different agents that compose it. There is a greater propensity for $\mathrm{VcC}$ between companies in the links closest to final demand. However, upward networks can be woven at various levels (with the manufacturer's suppliers) that later impact end customers. In this sense, to align the $\mathrm{VcC}$ of all the agents of the triad, the joint study of the motivations for buying and using the products can be promoted. In the same sense, agents of the triad should promote the participation of the end-user for the development of new products in a digitized and relational shopping environment.

Moreover, there are no significant differences in terms of the manufacturer's Social Satisfaction in both directions of the supply chain. This has a double reading from a managerial perspective: (1) in search of a more efficient supply chain, a better economic result derived from the relationship with the main customer is not always linked to socially differential satisfaction from the manufacturer's perspective; (2) the relationship with the main supplier reaches the same levels of Social Satisfaction as with the main customer, although economically the manufacturer does not perceive the same advantages. Suggestions for increasing the link of the social bond to economic results in the triad would be promoting activities with partners (workshops, discussion groups, etc.) in order to work on joint business development proposals.

\subsection{Limitations and Future Research Lines}

However, despite all of the above contributions and implications, this work presents limitations (all summarised in Table 11). The triad approach is based on the opinion of a single informant (manufacturer) without knowing that of the other agents in the 
chain (main supplier and main customer). In addition, the results obtained should be considered as an initial step in the investigation of $\mathrm{VcC}$ in industrial B2B relations, in this case exclusively for the furniture sector. The research should be compared with samples from other industries. In this way, the contextual nature of $\mathrm{VcC}$ could be verified, whose practices depend on the business environment where they are applied. On the other hand, the concept of $\mathrm{VcC}$ used could be expanded beyond the collaborative approach and the exchange of information between companies.

Table 11. Summary of main implications and limits of the study.

- $\quad$ Triadic approach of the manufacturer's perception of B2B relationships according to its role in the supply chain (supplier-manufacturer-client triad).

- Conceptual separation of social and economic aspects of Satisfaction, remarking the social bonds to business stakeholders.

- $\quad \mathrm{VcC}$ antecedent role of Satisfaction, with partial mediation of Social Satisfaction between VcC and Economic Satisfaction in the manufacturer-customer B2B relationship.

Implications

- Asymmetric $\mathrm{VcC}$ along the supply chain, being greater downwards (manufacturer-client) than upwards (supplier-manufacturer).

- $\quad$ Need for aligning VcC along the supply chain by integrating end-users insights for new product development with all agents of the triad.

- $\quad$ Triadic perceptions collected from a single informant perspective (manufacturer).

- $\quad \mathrm{VcC}$ is based on unidimensional collaboration and the exchange of information approach.

Limitations

- $\quad$ Limited to the furniture industry context.

- $\quad$ Pre-Covid-19 context data.

Last but not least, our results, obtained before the recent COVID-19 pandemic, should be cautiously interpreted and eventually measured again, as $\mathrm{VcC}$ in interfirm relationships may have dramatically changed, especially when considering both social and economic aspects together, as done in this study. Indeed, as recently stated [40], the economic shock brought on by the COVID-19 pandemic challenges any presumed advantages of B2B customer solutions and reveals the downsides of these complex offerings.

Finally, this work makes it possible to outline future lines of research. A dynamic approach could be introduced to know how $\mathrm{VcC}$ evolves throughout the B2B relationship in the supply chain, using longitudinal studies with companies. Another line would be the study of means-end models of $\mathrm{VcC}$ and Satisfaction variables with other constructs relevant for the B2B relationship, such as the company's technology bias, the quality of the relationship, or the impact on the results of the industrial relationship. Finally, the research could focus on the existence of synergistic networks or value creation ecosystems between companies, going beyond the traditional linear approach to the supply chain. This research approach would allow us to study all the B2B interactions between the actors in the triad and other actors (subcontractors, service companies, etc.) and the role played by the focal company in promoting $\mathrm{VcC}$ within the supply chain.

Author Contributions: Conceptualization, V.S.-V. and M.G.G.; Methodology, V.S.-V., and I.G.-S.; Validation, V.S.-V., M.G.G., and I.G.-S.; Formal Analysis, V.S.-V.; Investigation, V.S.-V., I.G.-S. and M.G.G.; Data Curation, V.S.-V.; Writing-Original Draft Preparation, V.S.-V., I.G.-S., and M.G.G.; Writing-Review and Editing, V.S.-V., I.G.-S., and M.G.G.; Visualization, V.S.-V., I.G.-S., and M.G.G.; Supervision, I.G.-S., and M.G.G.; Project Administration, I.G.-S. All authors have read and agreed to the published version of the manuscript.

Funding: Data collection for this research was funded by the Supporting Programme for Innovative Business Clusters of the Ministry of Industry, Commerce and Tourism, AEI-010500-2017-195.

Data Availability Statement: Data sharing not applicable.

Acknowledgments: This paper was developed within the Research Project ECO2016-76553-R of the Spanish Ministry of Economy, Industry and Competitiveness, National Research Agency. The authors are grateful to AIDIMME (Metal-processing, Furniture, Wood and Packaging Technology Institute) 
which runs the Spanish Furniture Market Observatory and the Wood-Furniture CV AEI and has kindly collaborated in the empiric study. This Observatory is funded by the Valencian Government through IVACE (The Valencian Institute of Business Competitiveness).

Conflicts of Interest: The authors declare no conflict of interest.

\section{References}

1. Vargo, S.L.; Lusch, R.F. Evolving to a New Dominant Logic for Marketing. J. Mark. 2004, 68, 1-17. [CrossRef]

2. Leclercq, T.; Hammedi, W.; Poncin, I. Ten years of value cocreation: An integrative review. Rech. Appl. Mark. (Engl. Ed.) 2016, 31, 26-60. [CrossRef]

3. Kohtamäki, M.; Rajala, R. Theory and practice of value co-creation in B2B systems. Ind. Mark. Manag. 2016, 56, 4-13. [CrossRef]

4. O'Cass, A.; Ngo, L.V. Creating superior customer value for B2B firms through supplier firm capabilities. Ind. Mark. Manag. 2012, 41, 125-135. [CrossRef]

5. Jacob, F.; Ulaga, W. The transition from product to service in business markets: An agenda for academic inquiry. Ind. Mark. Manag. 2008, 37, 247-253. [CrossRef]

6. Baines, T.S.; Bigdeli, A.Z.; Bustinza, O.F.; Shi, V.G.; Baldwin, J.; Ridgway, K. Servitization: Revisiting the state-of-the-art and research priorities. Int. J. Oper. Prod. Manag. 2017, 37, 256-278. [CrossRef]

7. Diesendorf, M. Sustainability and sustainable development. In Sustainability: The Corporate Challenge of the 21st Century; Allen \& Unwin: Sydney, Australia, 2000; Volume 2, pp. 19-37.

8. Goel, P. Triple bottom line reporting: An analytical approach for corporate sustainability. J. Financ. Acc. Manag. 2010, 1, 27-42.

9. Galvagno, M.; Dalli, D. Theory of value co-creation: A systematic literature review. Manag. Serv. Qual. Int. J. 2014, 24, 643-683. [CrossRef]

10. Ranjan, K.R.; Read, S. Value co-creation: Concept and measurement. J. Acad. Mark. Sci. 2016, 44, 290-315. [CrossRef]

11. Grönroos, C. Value co-creation in service logic: A critical analysis. Mark. Theory 2011, 11, 279-301. [CrossRef]

12. Pohlmann, A.; Kaartemo, V. Research trajectories of Service-Dominant Logic: Emergent themes of a unifying paradigm in business and management. Ind. Mark. Manag. 2017, 63, 53-68. [CrossRef]

13. Hein, A.; Weking, J.; Schreieck, M.; Wiesche, M.; Böhm, M.; Krcmar, H. Value co-creation practices in business-to-business platform ecosystems. Electron. Mark. 2019, 29, 503-518. [CrossRef]

14. Zhang, J.; Jiang, Y.; Shabbir, R.; Du, M. Building industrial brand equity by leveraging firm capabilities and co-creating value with customers. Ind. Mark. Manag. 2015, 51, 47-58. [CrossRef]

15. Kohtamäki, M.; Partanen, J. Co-creating value from knowledge-intensive business services in manufacturing firms: The moderating role of relationship learning in supplier-customer interactions. J. Bus. Res. 2016, 69, 2498-2506. [CrossRef]

16. Nätti, S.; Pekkarinen, S.; Hartikka, A.; Holappa, T. The intermediator role in value co-creation within a triadic business service relationship. Ind. Mark. Manag. 2014, 43, 977-984. [CrossRef]

17. Ferro, C.; Padin, C.; Svensson, G.; Payan, J. Trust and commitment as mediators between economic and non-economic satisfaction in manufacturer-supplier relationships. J. Bus. Ind. Mark. 2016, 31, 13-23. [CrossRef]

18. Ha, H.-Y.; Lee, M.-S.; Janda, S. Effects of economic and social satisfaction on partner trust. Eur. J. Mark. 2016, 50, 100-123. [CrossRef]

19. Del Bosque, I.A.R.; Agudo, J.C.; Martín, H.S. Determinants of economic and social satisfaction in manufacturer-distributor relationships. Ind. Mark. Manag. 2006, 35, 666-675. [CrossRef]

20. Holbrook, M.B. The Nature of Customer Value: An Axiology of Services in the Consumption Experience. In Service Quality: New Directions in Theory and Practice; SAGE Publications: Thousand Oaks, CA, USA, 2012; pp. 21-71.

21. Woodruff, R.B. Customer value: The next source for competitive advantage. J. Acad. Mark. Sci. 1997, 25, 139-153. [CrossRef]

22. Zeithaml, V.A. Consumer Perceptions of Price, Quality, and Value: A Means-End Model and Synthesis of Evidence. J. Mark. 1988, 52, 2-22. [CrossRef]

23. Holbrook, M.B. Consumer Value: A Framework for Analysis and Research; Routledge: London, UK, 1999.

24. Vargo, S.L.; Akaka, M.A.; Vaughan, C.M. Conceptualizing Value: A Service-ecosystem View. J. Creat. Value 2017, 3, 117-124. [CrossRef]

25. Claro, D.P.; Claro, P.B.O. Collaborative buyer-supplier relationships and downstream information in marketing channels. Ind. Mark. Manag. 2010, 39, 221-228. [CrossRef]

26. Albinsson, P.A.; Perera, B.Y.; Sautter, P.T. DART Scale Development: Diagnosing a Firm's Readiness for Strategic Value Co-creation. J. Mark. Theory Pract. 2016, 24, 42-58. [CrossRef]

27. Hamidi, F.; Gharneh, N.S. Impact of co-creation on innovation capability and firm performance: A structural equation modeling. AD-minister 2017, 30, 73-90. [CrossRef]

28. Hsu, Y. A value cocreation strategy model for improving product development performance. J. Bus. Ind. Mark. 2016, 31, 695-715. [CrossRef]

29. Franklin, D.; Marshall, R. Adding co-creation as an antecedent condition leading to trust in business-to-business relationships. Ind. Mark. Manag. 2019, 77, 170-181. [CrossRef]

30. Woratschek, H.; Horbel, C.; Popp, B. Determining customer satisfaction and loyalty from a value co-creation perspective. Serv. Ind. J. 2019, 40, 777-799. [CrossRef]

31. Merz, M.A.; Zarantonello, L.; Grappi, S. How valuable are your customers in the brand value co-creation process? The development of a Customer Co-Creation Value (CCCV) scale. J. Bus. Res. 2018, 82, 79-89. [CrossRef] 
32. Berenguer-Contrí, G.; González-Gallarza, M.; Ruiz-Molina, M.E.; Gil-Saura, I. Co-Creación de Valor en entornos B2B. In Proceedings of the Ponencia del Congreso AEMARK (Asociación Española de Marketing Académico y Profesional), Barcelona, Spain, 5-7 September 2018.

33. Thiruvattal, E. Impact of value co-creation on logistics customers' loyalty. J. Glob. Oper. Strat. Sourc. 2017, 10, 334-361. [CrossRef]

34. Cossío-Silva, F.-J.; Revilla-Camacho, M.-Á.; Vega-Vázquez, M.; Palacios-Florencio, B. Value co-creation and customer loyalty. J. Bus. Res. 2016, 69, 1621-1625. [CrossRef]

35. Anderson, J.C.; Narus, J.A. A Model of the Distributor's Perspective of Distributor-Manufacturer Working Relationships. J. Mark. 1984, 48, 62-74. [CrossRef]

36. Austen, V.; Herbst, U.; Bertels, V. When $3+3$ does not equal $5+1-$ New insights into the measurement of industrial customer satisfaction. Ind. Mark. Manag. 2012, 41, 973-983. [CrossRef]

37. Geyskens, I.; Steenkamp, J.-B.E. Economic and social satisfaction: Measurement and relevance to marketing channel relationships. J. Retail. 2000, 76, 11-32. [CrossRef]

38. Svensson, G.; Mysen, T.; Payan, J. Balancing the sequential logic of quality constructs in manufacturing-supplier relationshipsCauses and outcomes. J. Bus. Res. 2010, 63, 1209-1214. [CrossRef]

39. Ruiz-Martinez, A.; Gil-Saura, I.; Frasquet, M. Axes of relationship value between manufacturers and retailers. Manag. Decis. 2018, 56, 1716-1733. [CrossRef]

40. Bond, I.E.U.; De Jong, A.; Eggert, A.; Houston, M.B.; Kleinaltenkamp, M.; Kohli, A.K.; Ritter, T.; Ulaga, W. The Future of B2B Customer Solutions in a Post-COVID-19 Economy: Managerial Issues and an Agenda for Academic Inquiry. J. Serv. Res. 2020, 23, 401-408. [CrossRef]

41. Ngo, L.V.; O'Cass, A. Creating value offerings via operant resource-based capabilities. Ind. Mark. Manag. 2009, 38, 45-59. [CrossRef]

42. AIDIMME (Instituto Tecnológico Metalmecánico, Mueble, Madera, Embalaje y Afines). La Industria del Mueble en España, Edición 2020 ed; AIDIMME: Valencia, Spain, 2020.

43. Ringle, C.M.; Wende, S.; Becker, J.M. "SmartPLS 3" Boenningstedt: SmartPLS GmbH. 2015. Available online: http://www. smartpls.com (accessed on 1 November 2020).

44. Faul, F.; Erdfelder, E.; Lang, A.-G.; Buchner, A. G*Power 3: A flexible statistical power analysis program for the social, behavioral, and biomedical sciences. Behav. Res. Methods 2007, 39, 175-191. [CrossRef]

45. Cohen, J. Statistical Power Analysis for the Behavioral Sciences, 2nd ed.; Lawrence Erlbaum: New Jersey, NJ, USA, 1988.

46. Chung, J.; Huang, Y.; Jin, B.; Sternquist, B. The impact of market orientation on Chinese retailers' channel relationships. J. Bus. Ind. Mark. 2011, 26, 14-25. [CrossRef]

47. Henseler, J.; Ringle, C.M.; Sarstedt, M. A new criterion for assessing discriminant validity in variance-based structural equation modeling. J. Acad. Mark. Sci. 2015, 43, 115-135. [CrossRef]

48. Baron, R.M.; Kenny, D.A. The moderator-mediator variable distinction in social psychological research: Conceptual, strategic, and statistical considerations. J. Personal. Soc. Psychol. 1986, 51, 1173-1182. [CrossRef]

49. Kenny, D.A. Reflections on Mediation. Organ. Res. Methods 2007, 11, 353-358. [CrossRef]

50. Hayes, A.F. Beyond Baron and Kenny: Statistical Mediation Analysis in the New Millennium. Commun. Monogr. 2009, 76, 408-420. [CrossRef]

51. Otuya, W. Kenny and Baron 4 Step Analysis (1986): A Case of Employee Job Satisfaction as a Mediator Between Ethical Climate and Performance among Sugarcane Transport Smes in Western Kenya. J. Econ. Sustain. Dev. 2019, 10, $108-118$.

52. Hair, J.F.; Hult, G.T.M.; Ringle, C.; Sarstedt, M. A Primer on Partial Least Squares Structural Equation Modeling (PLS-SEM); Sage Publications: New York, NY, USA, 2017.

53. Troisi, O.; Santovito, S.; Carrubbo, L.; Sarno, D. Evaluating festival attributes adopting S-D logic: The mediating role of visitor experience and visitor satisfaction. Mark. Theory 2019, 19, 85-102. [CrossRef]

54. Botti, A.; Grimaldi, M.; Tommasetti, A.; Troisi, O.; Vesci, M. Modeling and Measuring the Consumer Activities Associated with Value Cocreation: An Exploratory Test in the Context of Education. Serv. Sci. 2017, 9, 63-73. [CrossRef] 